\title{
Review \\ The Role of Extracellular Vesicles from Human Macrophages on Host-Pathogen Interaction
}

\author{
Luis A. Arteaga-Blanco ${ }^{1, *(D)}$ and Dumith Chequer Bou-Habib ${ }^{1,2, *(D)}$ \\ 1 Laboratory on Thymus Research, Oswaldo Cruz Institute/Fiocruz, Rio de Janeiro 21040-900, Brazil \\ 2 National Institute of Science and Technology on Neuroimmunomodulation, Rio de Janeiro 21040-900, Brazil \\ * Correspondence: luis.arteagablanco@gmail.com (L.A.A.-B.); dumith@ioc.fiocruz.br or \\ dumith.chequer@gmail.com (D.C.B.-H.)
}

Citation: Arteaga-Blanco, L.A.; Bou-Habib, D.C. The Role of Extracellular Vesicles from Human Macrophages on Host-Pathogen Interaction. Int. J. Mol. Sci. 2021, 22 10262. https://doi.org/10.3390/ ijms221910262

Academic Editor: Abdelnaby Khalyfa

Received: 29 May 2021

Accepted: 21 June 2021

Published: 23 September 2021

Publisher's Note: MDPI stays neutral with regard to jurisdictional claims in published maps and institutional affiliations.

Copyright: (C) 2021 by the authors Licensee MDPI, Basel, Switzerland. This article is an open access article distributed under the terms and conditions of the Creative Commons Attribution (CC BY) license (https:// creativecommons.org/licenses/by/ $4.0 /)$.
Abstract: The nano-sized membrane enclosed extracellular vesicles (EVs) released by virtually all cell types play an essential role in intercellular communication via delivering bio-molecules, such as nucleic acids, proteins, lipids, and other molecules to recipient cells. By mediating an active and steady-state cell-to-cell communication, EVs contribute to regulating and preserving cellular homeostasis. On the other hand, EVs can also spread pathogen-derived molecules during infections, subverting the host immune responses during infections and thus worsening pathophysiological processes. In recent years, the biological functioning of EVs has become a widespread research field in basic and clinical branches of medical sciences due to their potential role in therapeutic applications for several diseases. This review aims to summarize the main recent findings regarding the implication of EVs shed by human macrophages (M $\Phi$-EVs) and how they can modulate the host immune response to control or increase the damage caused by infectious agents. We will also present the methods used to describe M $\Phi$-EVs, as well as the potential of these EVs as disease diagnostic tools for some human pathogens. We believe that an in-depth understanding of the host-pathogen interactions mediated by $M \Phi-E V s$ may trigger the development of innovative therapeutic strategies against infectious diseases.

Keywords: extracellular vesicles; human macrophages; innate immunity; host-pathogen interaction and infectious diseases

\section{Introduction}

Many years later, facing the vast progress in understanding the macrophage role in homeostasis, researchers turn their minds to that remote sunny afternoon by the sea, when Elie Metchnikoff described and portrayed these cells for the first time. Macrophages were then defined only by their ability to engulf foreign bodies (see Acknowledgments). Today, we know that in addition to being involved in host defense and other biological functions, macrophages participate in cellular communication through extracellular vesicles (EVs), which are small lipid bilayer-enclosed structures released from cells in the extracellular space $[1,2]$. EVs are implicated in intercellular communication without direct cell-to-cell contact trough the transport and transfer of bioactive molecules such as nucleic acids, proteins, lipids, metabolites, cytokines, chemokines, among other molecules, to recipient cells [3,4] (Figure 1). All these components are further processed to promote physiological or pathological alterations in recipient cells, including modulation of the effector activities of cells of the immune system [4,5]. Although there has been much progress in recent years on the understanding of the fundamental biology of EVs, some aspects related to their biogenesis, secretion mechanisms, interaction with the recipient cell, and biological function remains unclear $[4,6]$. Therefore, more research focused on the comprehension of the mechanisms that mediate the biological effects of EVs on their cellular targets under specific physiological or pathological condition could clarify open questions in the field of 
extracellular vesicles, including EV diversity, composition, pathophysiology activities, and their role on host-pathogen interactions.

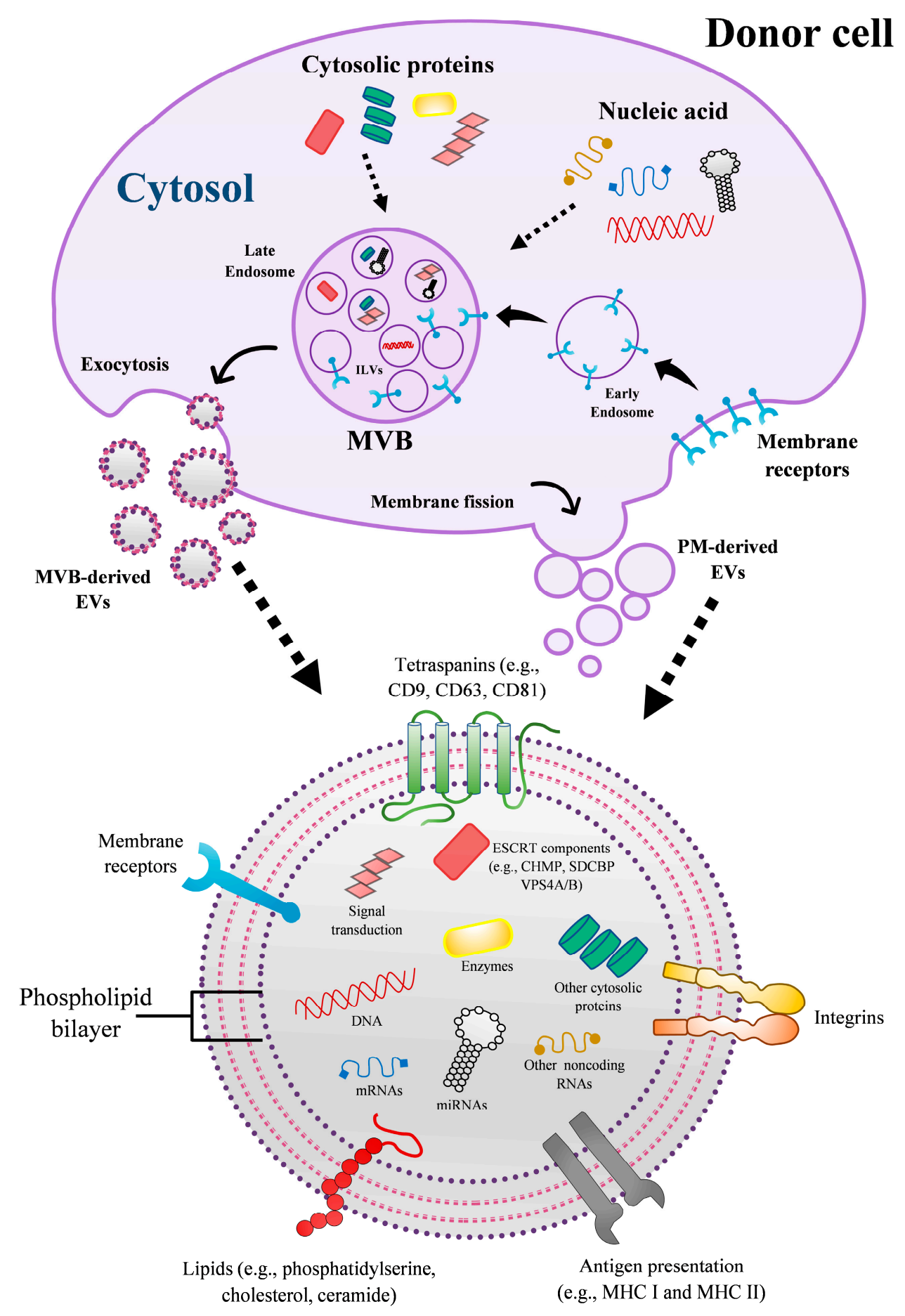

Figure 1. Schematic representation of origin and composition of EVs secreted by eukaryotic cell. PM-derived EVs originate directly from the cell membrane fission, whereas EVs of endosomal system originate from ILVs contained in cytosolic MVBs, which later fuse with the PM releasing the vesicles in the outer space. EVs can carry proteins, lipids, and nucleic acids. Some of the listed components represented in the figure may be enriched in some subtypes of EVs and not in others. For instance, ESCRTs components (e.g., CHMP, SDCBP, VPS4A/B) are highly enriched in MVB-derived EVs rather than PM-derived EVs. Abbreviations: CHMP, charged multivesicular body protein; ESCRT, endosomal sorting complex required for transport; ILVs, intraluminal vesicles; MVBs, multivesicular bodies; MHC, major histocompatibility complex; PM, plasma membrane; SDCBP, syndecan binding protein; VPS4A/B, vacuolar protein sorting-associated protein 4A/B. 
Different types or subtypes of vesicles can be secreted by the same cell. To date, the biosynthesis pathways (vesicles origin) and biophysical and biochemical characteristics (size, shape, densities, biochemical markers, protein, and lipid composition) are features commonly used to classify EVs [1,3]. For instance, based on size and origin, vesicles can be categorized into large EVs (LEVs, >300 $\mathrm{nm}$ in diameter), released by the fission of the plasma membrane from apoptotic or healthy cells [1,7]; intermediate EVs (IEVs, 150-300 $\mathrm{nm})$, and small EVs (sEVs, $<150 \mathrm{~nm}$ ), these latter types originated from plasma membrane or endosomal system $[6,8]$. sEVs from the endosomal system originate from intraluminal vesicles (ILVs) contained in cytosolic multivesicular bodies (MVBs), which later fuse with the plasma membrane releasing the vesicles in the outer space $[9,10]$ (Figure 1).

Many studies have shown multiple ways by which several pathogens modify EV synthesis, enhancing or restricting their replication and dissemination in receptor cells [11-13]. In fact, there is accumulating evidence of the release of vesicles from several sources during infectious diseases, acting both in pathogen-pathogen inter-communication as well as in host-pathogen interaction [11,14-19]. However, despite the increasing number of reviews describing and discussing the involvement and role of EVs in the complex scenario of host-pathogen interaction, up-to-date information about the specific impact of vesicles released by human macrophages on the progression of infectious illnesses is quite limited.

Macrophages are key phagocytic mononuclear cells of the myeloid lineage distributed in different organs (e.g., liver, lungs, skin, heart), and every tissue of the immune system, such as lymph nodes, spleen, and bone marrow [20-22]. Macrophages are implicated in multiple activities essential for bone remodeling, tissue development and homeostasis, resolution of inflammation, and wound healing. In addition, these cells induce and orchestrate the innate and acquired immunity against infectious agents through a variety of cell processes, such as antigen presentation, secretion of pro- and anti-inflammatory cytokines, chemokines, and production of antibacterial peptides and antiviral compounds (e.g., IL-6, IL-1 $\beta$, LL-37, reactive oxygen, and nitrogen species) [23-25]. Given their ability to recognize and respond to a wide range of stimuli and pathogens through phagocytic activity and secretion of soluble mediators, which may favor or inhibit the survival and persistence of infectious agents, understanding the intricate and complex roles of macrophages in host-pathogen interaction is a challenging task, whichrequires permanent attention of investigators to new concepts often arising in this field of life science [26,27].

This review aims to summarize principal findings regarding the implication of EVs released by human macrophages (M $\Phi$-EVs) during bacterial, viral, fungal, and parasitic infection, emphasizing their role in host-pathogen interaction and their functional impacts on the host's immune response. We will also present an overview of the isolation and characterization methods to describe vesicles from human macrophages and discuss their potential use as diagnostic tools for human infectious diseases. Highlighting the contribution of EVs to the ability of macrophages to regulate pathogen growth and propagation can support the comprehension of how cellular communication is critical to developing strategies to attenuate cellular and tissue damage caused by infectious agents.

Given the growing scientific interest in the role played by EVs in cellular communication and the undisputed importance of macrophages in the generation of an effective immune response and preservation of the homeostasis during infections by all types of pathogens, this review will encompass the more recent advances regarding EVs released from human macrophages and their ability to regulate the growth and dissemination of infectious agents.

\section{Immunoregulatory Properties of Macrophage-Derived EVs}

Numerous studies have widely documented the ability of EVs to regulate immune responses, mainly in the context of cancer and autoimmunity [28-30]. Cells of the immune system, such as macrophages, monocytes, neutrophils, dendritic cells (DCs), Natural Killer cells, T and B lymphocytes can shed EVs with specific cargo, resembling their origin and function [31,32], thus participating in cellular communication independently of cell- 
cell contact or soluble factors (e.g., cytokines and chemokines) [33]. In recent years, some authors have unveiled the emerging role of vesicles secreted by human macrophages on the direct or indirect regulation of innate and adaptive immunity [34-36]. As such, early studies showed that EVs released by circulating human monocyte-derived macrophages (MDM) induced proliferation and activation of CD4+ and CD8+ T cells in vitro and in vivo after intranasal injection in mice. This EV-mediated stimulus was depended on DCs activity and resulted in the induction of effector memory T cells [37]. Furthermore, macrophage-derived vesicles can carry MHC class II and costimulatory molecules, similarly to DC-derived EVs, suggesting a role in antigen presentation [36,38]. In addition, M $\Phi$-EVs have also been shown to induce the differentiation of human monocytic THP-1 cells into macrophages through the transfer of miR-223, which is an essential regulator of myeloid cell proliferation and differentiation [34]. An interesting functional opposite effect has emerged from studies with vesicles derived from differentially activated macrophages. As such, EVs derived from pro-inflammatory macrophages induce the secretion of Th1 cell-promoting cytokines (IL-12 and IFN- $\gamma$ ) in both macrophages and DC cell lines and elicit a more robust antigen specific cytotoxic T cell response in vivo when administered together with a peptide vaccine. In contrast, EVs released by anti-inflammatory macrophages enhanced the secretion of the anti-inflammatory cytokines IL-4 and IL-10 by macrophages and DCs [35]. These and other studies indicate that $\mathrm{M} \Phi-\mathrm{EV}$ s can regulate inflammatory reactions and modulate innate immune responses, with repercussions in the outcome of infectious diseases, either by inhibiting or favoring pathogen replication, therefore ameliorating or worsening infectious illnesses. In the following sections, we will summarize and discuss the effects of human macrophage-derived EVs on host-pathogen interactions.

\section{Human Macrophage-Derived EVs and Bacterial Infections}

Many reports have described that during a bacterial invasion, vesicles secreted by infected macrophages may induce specific biological functions in recipient cell, such as enhancement of microbial survival and dissemination, or restriction and blockade of bacterial replication [12,39]. For instance, Volgers and colleagues (2017) reported that EV released by THP-1 macrophage-like cells infected with common respiratory pathogens Haemophilus influenzae, Moraxella catarrhalis, Streptococcus pneumoniae, or Pseudomonas aeruginosa, or with bacterial-derived outer membrane vesicles (OMV), elicit strong release of pro-inflammatory mediators (TNF- $\alpha$, IL-8, and IL-1 $\beta$ ) by naïve recipient macrophages. In addition, M $\Phi$-EVs were also found to enhance bacterial adherence and increase the number of intracellular bacteria [40]. These and other findings quoted in the following sections show that EVs secreted by infected macrophages may play a dual role during bacterial infection, either dampening the host response, thereby contributing to microbial survival, or stimulating the immune system, thus favoring the restriction of pathogen replication (Table 1).

Table 1. Available studies * of EVs released by human macrophages during infectious diseases.

\begin{tabular}{|c|c|c|c|c|}
\hline Pathogen & $\begin{array}{l}\text { EV Effect on } \\
\text { Pathogenesis }\end{array}$ & Source of EVs & Outcome in Recipient Cells & References \\
\hline \multicolumn{5}{|c|}{ BACTERIA } \\
\hline $\begin{array}{l}\text { Haemophilus influenzae, Moraxella } \\
\text { catarrhalis, Streptococcus pneumoniae, } \\
\text { and Pseudomonas aeruginosa }\end{array}$ & Dual role & THP-1 & $\begin{array}{c}\text { Trigger and/or dampen } \\
\text { immune responses against } \\
\text { bacterial infection }\end{array}$ & {$[40]$} \\
\hline Escherichia coli & Dual role & THP-1 & $\begin{array}{l}\text { Favor or inhibit bacterial } \\
\text { replication }\end{array}$ & {$[41]$} \\
\hline $\begin{array}{c}\text { Mycobacterium bovis Bovis Bacillus } \\
\text { Calmette-Guerin (BCG) }\end{array}$ & Enhancement & $\begin{array}{c}\text { Primary } \\
\text { monocyte-derived } \\
\text { macrophage (MDM) }\end{array}$ & $\begin{array}{l}\text { Increase bacterial replication } \\
\text { and survival }\end{array}$ & {$[42]$} \\
\hline
\end{tabular}


Table 1. Cont.

\begin{tabular}{|c|c|c|c|c|}
\hline Pathogen & $\begin{array}{l}\text { EV Effect on } \\
\text { Pathogenesis }\end{array}$ & Source of EVs & Outcome in Recipient Cells & References \\
\hline \multirow{2}{*}{ Treponema pallidum } & Enhancement & THP-1 & $\begin{array}{l}\text { Affect adhesion and } \\
\text { permeability of human } \\
\text { endothelial cells }\end{array}$ & [43] \\
\hline & Enhancement & THP-1 & $\begin{array}{l}\text { Increase evasion of host } \\
\text { immune response }\end{array}$ & [44] \\
\hline M. tuberculosis (M. tb) & Enhancement & THP-1 & $\begin{array}{l}\text { Induce changes in EV protein } \\
\text { composition to increased } \\
\text { bacterial infection }\end{array}$ & [45] \\
\hline $\begin{array}{l}\text { Mycobacterium tuberculosis, } M . \text { bovis } \\
\text { BCG, Salmonella typhimurium }\end{array}$ & Inhibition & THP-1 & $\begin{array}{l}\text { Enhance host immune } \\
\text { response }\end{array}$ & [46] \\
\hline \multirow{2}{*}{ M. tuberculosis (M. tb) } & Inhibition & THP-1 & $\begin{array}{c}\text { Promote inflammation, } \\
\text { intercellular communication, } \\
\text { and cell migration to contain } \\
\text { bacterial infection }\end{array}$ & [47] \\
\hline & Inhibition & THP-1 & $\begin{array}{l}\text { Induce type I IFN response } \\
\text { against } \mathrm{M} \text {. tb infection }\end{array}$ & [48] \\
\hline $\begin{array}{l}\text { Mycobacterium avium sp. } \\
\text { paratuberculosis }\end{array}$ & Inhibition & THP-1 & $\begin{array}{l}\text { Enhance host immune } \\
\text { response }\end{array}$ & [49] \\
\hline M. avium & Inhibition & THP-1 & $\begin{array}{l}\text { Enhance host immune } \\
\text { response }\end{array}$ & [50] \\
\hline M. bovis BCG & Inhibition & THP-1 & $\begin{array}{l}\text { Increase host innate immune } \\
\text { response via endosomal TLR-7 } \\
\text { activation }\end{array}$ & [51] \\
\hline Legionella pneumophila & Inhibition & THP-1 or MDM & $\begin{array}{l}\text { Stimulate immune response to } \\
\text { control bacterial infection }\end{array}$ & [52] \\
\hline $\begin{array}{c}\text { Salmonella enterica serovar } \\
\text { Typhimurium }\end{array}$ & Inhibition & THP-1 & $\begin{array}{l}\text { Enhance the release of } \\
\text { pro-inflammatory mediators } \\
\text { to control bacterial infection }\end{array}$ & [53] \\
\hline \multicolumn{5}{|c|}{ VIRUSES } \\
\hline \multirow{7}{*}{ HIV-1 } & Enhancement & MDM & Increase viral infection & [54] \\
\hline & Enhancement & U937 or MDM & $\begin{array}{l}\text { Increase HIV-1 reactivation in } \\
\text { latent cellular reservoirs }\end{array}$ & [55] \\
\hline & Enhancement & $\begin{array}{l}\text { THP-1 or alveolar } \\
\text { macrophages }\end{array}$ & $\begin{array}{l}\text { Increase chronic immune } \\
\text { activation through HIV } \\
\text { vmiR88 and vmiR99 }\end{array}$ & [56] \\
\hline & Enhancement & MDM & Increase viral infection & [57] \\
\hline & Enhancement & THP-1 or MDM & $\begin{array}{l}\text { Affect epithelial barrier } \\
\text { integrity and mitochondrial } \\
\text { activity which contribute to } \\
\text { immune dysfunctions against } \\
\text { viral infection }\end{array}$ & [58] \\
\hline & Enhancement & MDM & $\begin{array}{l}\text { Promote hyperproliferation of } \\
\text { pulmonary arterial smooth } \\
\text { muscle cells }\end{array}$ & [59] \\
\hline & Enhancement & MDM & $\begin{array}{l}\text { Induce neuronal apoptosis and } \\
\text { dysfunction through } \\
\text { cathepsin B }\end{array}$ & [60] \\
\hline H1N1 & Enhancement & MDM or THP-1 & $\begin{array}{l}\text { Affect innate immune } \\
\text { response in macrophages and } \\
\text { DC against viral infection }\end{array}$ & [61] \\
\hline DENV & Inhibition & U937 & $\begin{array}{l}\text { Induce activation of } \\
\text { endothelial cells and promote } \\
\text { endothelial barrier changes to } \\
\text { increase proinflammatory } \\
\text { response during infection }\end{array}$ & [62] \\
\hline
\end{tabular}


Table 1. Cont.

\begin{tabular}{ccccc}
\hline Pathogen & $\begin{array}{c}\text { EV Effect on } \\
\text { Pathogenesis }\end{array}$ & Source of EVs & Outcome in Recipient Cells & References \\
\hline HBV & Inhibition & THP-1 & Induce anti-HBV activity & [63] \\
\hline HCV & Inhibition & MDM & Induce anti-HCV activity & [64] \\
\cline { 2 - 5 } & Inhibition & MDM or THP-1 & Induce anti-HCV activity & [65] \\
\hline Toxoplasma gondii & Inhibition & PARASITES & THP-1 & $\begin{array}{c}\text { Enhance host immune } \\
\text { response }\end{array}$ \\
\hline Trypanosoma cruzi & Enhancement & THP-1 & $\begin{array}{c}\text { Inhibit innate immune } \\
\text { response }\end{array}$ \\
\cline { 2 - 5 } & Undefined & THP-1 & Undefined & [66] \\
\hline Fungal cell components: $\beta$-glucans & Inhibition & FUNGI & MDM & $\begin{array}{c}\text { Activate innate immune } \\
\text { system via Dectin-1 receptor }\end{array}$ \\
\hline Candida albicans & Inhibition & THP-1 & $\begin{array}{c}\text { Enhance host immune } \\
\text { response }\end{array}$
\end{tabular}

Abbreviations: DENV, Dengue virus; HBV, Hepatitis B virus; HCV, Hepatitis C virus; HIV-1, human immunodeficiency viruses type I; HIN1, influenza A virus subtype H1N1; MDM, circulating human monocyte-derived macrophages. * PubMed, May 2021.

\subsection{EVs from Macrophages Can Potentiate Bacterial Infections}

Studies have shown that EVs bearing bacterial components stimulate the host immune response to promote pathogen invasion, replication, and survival in recipient cells [12,39]. For example, EVs from Escherichia coli-infected THP-1 cells and E. coli-infected T84 intestinal epithelial cells (IECs) can increase bacterial replication in naïve macrophages by stimulating the secretion of pro-inflammatory cytokines (TNF- $\alpha$ and IL-6) via nuclear factor-kappa B (NF-kB) and MAPK pathways. In contrast, EVs derived from uninfected THP-1 can reduce E. coli intracellular replication. These findings suggest that vesicles, upon altering the functioning of immune cells, can either favor or inhibit bacterial replication [41]. Moreover, circulating human monocyte-derived macrophages release EVs packing a set of miRNAs (miRs-1224, -1293, -425, -4467, -4732, -484, -5094, -6848, -6849, -96, and -4488) involved in cell metabolism pathways (e.g., carbon, amino acid, fatty acids, sugar metabolism) upon infection with Mycobacterium bovis Bacillus Calmette-Guerin (BCG), which may reprogram the metabolic pathways and modulate immune surveillance to allow bacterial invasion and survival in recipient BCG-infected macrophages [42]. EVs from infected macrophages can also modulate the functionality of endothelial cells, as vesicles released by Treponema pallidum-infected THP-1 cells affected the adhesion and permeability of human umbilical vein endothelial cells (HUVECs) through upregulating the expression of the intercellular cell adhesion molecule 1 (ICAM-1), vascular cell adhesion molecule (VCAM-1), vascular endothelial growth factor (VEGF) and IL-8 [43]. Later, the same group showed that vesicles from T. pallidum-infected THP-1 cells transferred to vascular endothelial cells (VECs) the miR-146a-5p involved in the reduction of the monocyte transendothelial migration and endothelial permeability as a result of decreased expression of junctional adhesion molecule C (JAM-C), leading to bacterial evasion from the immune response in the EVs recipient cells [44]. Pathogens can also induce changes in EV protein composition, as particles secreted by Mycobacterium tuberculosis (Mtb)-infected THP-1 cells packaged more membrane associated proteins $(>60 \%)$ than EVs from uninfected cells [45]. Most of the proteins found in EVs from Mtb-infected cells are involved in metabolic processes, binding, and immune response [70]. Therefore, $M$. tuberculosis may use EVs shed by infected cells as an alternative strategy to ensure a microbial-favored host-pathogen interaction in nearby EVs recipient infected cells. 


\subsection{Macrophage-EVs Can Contribute to Development of Immune Responses against Bacterial Infections}

On the other hand, EVs can also function as antigen carriers to promote host response against bacterial infections [12,39]. Most of the available studies showing the role of M $\Phi-E V s$ in inducing anti-bacterial responses were carried out with Mycobacterium sp, a genus with a significant worldwide impact on public health [71,72]. However, other intracellular bacteria with the ability to modify EV cargo to regulate both innate and adaptive immune responses have also been a matter of investigations, most of them using THP-1 cells as a donor of EVs (Table 1). Bhatnagar et al. 2007 showed that vesicles released from macrophages infected with M. tuberculosis, M. bovis BCG or Salmonella typhimurium transport pathogen-associated molecular patterns (PAMPs), which can stimulate pro-inflammatory responses in recipient naïve macrophages via Toll-like receptors (TLRs) and myeloid differentiation factor 88 (MyD88) pathways [46]. Similarly, EVs derived from mycobacteria-infected macrophages carrying mycobacterial antigens activate M. tuberculosis-specific CD4+ T cells in vivo and in vitro in a dendritic cell-dependent manner. In addition, $M$. tuberculosis-infected mice injected with EVs from $M$. tuberculosis-infected macrophages showed heightened production of TNF- $\alpha$ and recruitment of immune cells to the infection site to control bacterial replication [47]. Hare and colleagues (2015) described that $M$. tuberculosis infection increased the EV packaging of proteins with immune functions, including interferon-stimulated gene (ISG)-15 and interferon induced protein with tetratricopeptide repeats (IFIT)-1, -2, and -3 [48]. Furthermore, EVs from M. tuberculosisinfected cells increased in recipient uninfected THP-1 cells, the gene expression of ISG15, IFIT1, -2, -3, Interferon-induced transmembrane protein (IFITM) $-1 / 3$, and the secretion of pro-inflammatory cytokines IL-8, Interferon gamma inducible protein 10 (IP-10) and macrophage inflammatory protein-1 Alpha (MIP-1 $\alpha)$ [48]. Studies conducted by Wang and colleagues (2014) showed that both Mycobacterium avium sp. Paratuberculosis and particles shed from uninfected macrophages enhanced the expression of surface molecules CD80 and CD86 (required for T lymphocyte activation) and stimulate the secretion of TNF- $\alpha$ and IFN- $\gamma$ in recipient macrophages, leading to immune activation $[49,73]$. In addition, uninfected macrophages exposed with EVs from M. avium-infected macrophages increased the expression of CD40, CD80, CD81, CD86, HLA-DR, and CD195, and enhanced the secretion of IL-6, IL-8, IL-10, IFN- $\gamma$, and TNF- $\alpha$ [50]. Recent studies demonstrated that M. bovis-infected or PAMP-stimulated THP-1 cells secrete EVs packaging 5'-tRNA halves, which in turn induce innate immune responses via endosomal TLR-7 activation in recipient THP-1 cells [51]. Other examples of the ability of EVs released by macrophages to modulate the immune response against pathogens come from macrophages infected with Legionella pneumophila or L. pneumophila-derived outer membrane vesicles (OMVs), whose EVs stimulate the secretion of several pro-inflammatory mediators (e.g., IL-1 $\beta$, IFN- $\beta$, MCP-1, TNF- $\alpha$ ) in bystander macrophages via TLR-2 activation. The cytokines and chemokines produced by recipient macrophages may additionally activate epithelial cells, further enhancing the secretion of the chemokine CXCL8 and the recruitment of alveolar macrophages and neutrophils, eventually leading to inhibition of bacterial growth in vivo [52]. Similar control of bacterial replication was found when naïve macrophages were exposed to LPS-loaded EVs released by macrophages infected with Salmonella enterica serovar Typhimurium, mediated by enhanced cellular secretion of TNF- $\alpha$ and IL- $1 \beta$ via TLR-4 signaling pathway [53].

\section{EVs from Human Macrophages and Viral Infections}

Many reports have demonstrated that vesicles of several sources can play important roles during viral infections, leading to both stimulatory and inhibitory activities $[13,39]$. Most of the available studies published on EVs were performed with HIV-1 infection, either in vitro or ex vivo [74,75]. Because comprehensive reviews of the effect of EVs from different cellular models on viral infections were recently published elsewhere [13,74-80], we will focus here on the current knowledge of the pro- and anti-viral functions reported for M $\Phi$-EVs (Table 1). 


\subsection{Stimulatory Role of Macrophage-Derived EVs during Viral Infections}

Several authors reported that some viruses may exploit the endosomal machinery that produces extracellular vesicles for viral particle formation [81,82]. In this sense, EVs shed by infected cells from different sources carry viral particles or viral components (e.g., proteins and nucleic acids) that can impair host defense to promote viral infectivity and propagation $[13,79,83]$. For example, the transmission of human immunodeficiency viruses 1 (HIV-1) to neighboring uninfected macrophages is favored by M $\Phi$-EVs loading viral components, an infectious process facilitated by a range of cell surface receptors and adhesion molecules [54]. Similarly, vesicles from HIV-infected macrophages containing the HIV-1 Nef protein, together with TNF- $\alpha$ and ADAM17, can activate latent HIV-1 infections in primary CD4+ T lymphocytes and macrophages, thus promoting viral infectivity mediated by M $\Phi$-EVs [55]. THP-1 or primary human alveolar macrophages infected with HIV-1 can produce EVs loaded with virus-derived miRNAs (vmiR88 and vmiR99) that, when internalized by uninfected macrophages, stimulate a TLR8-dependent signaling pathway, resulting in TNF- $\alpha$ release [56]. These data suggest a potential role for HIV-1-derived vmiRNAs released from infected macrophages to influence viral pathogenesis. In fact, some authors reported that HIV-1 infection increased the secretion of macrophage-EVs packing miRNAs, which may play a role in viral infectivity and dissemination $[57,84]$. In addition, EVs loaded with miRNAs miR-23a and miR-27a secreted by Tat- and gp120-treated macrophages, harm the epithelial barrier integrity and altered mitochondrial activity, respectively, when delivered to alveolar epithelial cells [58]. These findings suggest that miRNAs carried by vesicles from HIV-1-infected macrophages may modulate the alveolar microenvironment to increase susceptibility to lung infection and injury, thus facilitating HIV-1 invasion and propagation.

Evidence has also pointed to the fact that M $\Phi$-EVs secreted during HIV-1 infection can trigger secondary diseases [79]. For example, HIV-1-infected macrophages promote pulmonary smooth muscle proliferation through EVs delivering pro-survival miRNA-130a, which may play role in the development of pulmonary arterial hypertension [59]. Therefore, EVs released by HIV-1-infected macrophages could participate in the dysfunction of HIV-1 non-permissive vascular cells and be involved in the development of a pulmonary disorder. Moreover, EVs released from HIV-1-infected macrophages can transfer cathepsin B (CATB) and serum amyloid p component (SAPC) to neurons, inducing neuronal apoptosis. Pretreatment with anti-CATB and -SAPC antibodies decreased the cleavage of caspase- 3 and restored neurons functionality [60], suggesting that both proteins loaded in macrophagederived EVs may represent a therapeutic target against HIV-associated neurocognitive disorders. Finally, macrophages infected with H1N1 release vesicles containing miR-451, which attenuate, in EV recipient macrophages and DCs, the expression of IFN- $\beta$ and IL- 6 induced by formalin-inactivated whole-virus vaccine through the inhibition of proteins FOXO3 and ZFP36 $[61,85,86]$, suggesting that EVs loaded with miRNAs can interfere with the innate immune response to inactivated whole virus.

\subsection{Inhibitory Effects of Macrophage-Derived EVs during Viral Infections}

Another set of studies have reported the opposite effect of M $\Phi-E V$ s on viral infection, showing that they can act as inhibitors of viral transmission and replication. For instance, U937 macrophage cell line infected with Dengue Virus 2 (DENV-2) release EVs packed with viral NS3 protein and different miRNAs, which induce changes in the expression of VEcadherin and ICAM and increase the production TNF- $\alpha$, IP-10, IL-10, RANTES, and MCP-1 in endothelial cells, resulting in protection during early stages of DENV infection [62]. Similarly, EVs secreted by macrophage infected with Hepatitis B virus (HBV) deliver IFNinduced antiviral products to hepatocytes through the T-cell immunoglobulin and mucin domain 1 (TIM-1), a receptor used by Hepatitis A Virus (HAV), indicating that anti-HBV effector molecules can be transferred by macrophage-derived EVs [63]. Moreover, EVs secreted by Hepatitis C virus (HCV)-infected macrophages contain miR-29 that, when transferred to hepatocytes, trigger innate responses against the virus [64]. It was also 
shown that IFN-pulsed macrophages release vesicles that induce a late, but long-lasting, inhibition of HCV replication in hepatocytes [65]. In summary, these studies suggest that vesicles shed by human macrophages can enhance the immune response in recipient cell by delivering viral components, miRNAs, or interferon-stimulated genes able to restrict viral infection.

\section{EVs from Macrophages and Parasitic Infections}

The role of EVs from parasitized cells with Leishmania and Toxoplasma species, among other protozoan parasites, has been well studied in murine macrophages [87-90]. Concerning human macrophages, the studies are limited (Table 1). For instance, it was observed that EVs released from macrophages infected with Toxoplasma gondii transport PAMPs, which can stimulate pro-inflammatory responses in recipient macrophages via TLRs and MyD88 pathways [46]. Furthermore, Cestari and colleagues (2012) reported that vesicles from Trypanosoma cruzi-infected THP-1 cells inhibited, the complement-mediate parasite lysis through the inactivation of the classical and lectin pathway $\mathrm{C} 3$ convertases (C4b2a), indicating that $\mathrm{T}$. cruzi can use EVs to inhibit the host immune response and, thus, enhance parasite survival and dissemination [66]. Recent findings showed that EVs released by T.cruzi-infected THP-1 cells activate TLR- 2 and NF-kB pathway in recipient macrophages, resulting in enhanced production of pro-inflammatory cytokines (TNF- $\alpha$, IL-6, and IL-1 $\beta$ ) to maintain the inflammatory response in the course of infection [67]. These findings suggest that $M \Phi-E V s$ may enhance or impair host defense, thus controlling or facilitating the parasite survival and propagation.

\section{Macrophage-Derived EVs and Fungal Infections}

There are limited data on human macrophage-EVs in the context of fungal infections (Table 1). A quantitative proteomic study combined with bioinformatic analysis showed that the cargo of vesicles from monocyte-derived macrophages upon cell stimulation with linear $(1,3)-\beta$-glucan (curdlan) was highly enriched with integrins and other adhesion molecules. These EVs could induce host innate immune response via Dectin-1 receptor and contribute to spreading the infection by transferring danger signals directly to target cells [68]. Therefore, the functional roles of EVs from $\beta$-glucan-activated macrophages remain to be elucidated. Additional proteomic studies of particles secreted by macrophages infected with Candida albicans showed an increase number of proteins involved in cell signaling, cytoskeletal reorganization, and immune response [69]. In addition, THP-1derived EVs, both from uninfected and Candida-infected macrophages, were able to induce similar effector functions in naïve macrophages by activating ERK and p38 kinases pathways, leading to the secretion of pro-inflammatory cytokines to control C. albicans infection [69]. Given the limited number of studies evaluating the possible role of EVs from human macrophages on fungal infections, more research is needed and encouraged to strengthen our knowledge about the impacts of vesicles secreted from these cells on the progression of diseases caused by pathogenic fungi.

\section{Methods for Isolation and Characterization of EVs from Human Macrophages}

At the same time that major advances were achieved in the understanding of the role of EVs in cellular communication and homeostasis, as well as of their clinical use as biomarkers or for therapeutic purposes, a large variety of technologies and strategies for isolation and characterization of extracellular vesicles were designed, developed, and improved [8,91,92]. Because comprehensive reviews of the available methods for EV analysis describing their working principles, improvements, and limitations were recently published elsewhere [13,93-95], here we will highlight the techniques more frequently used for studying EVs secreted by human macrophages (Table 2). 
Table 2. Methods applied to separate and characterize EVs from human macrophages.

\begin{tabular}{|c|c|c|c|}
\hline Source of EVs & Isolation Methods & Characterization Methods & References \\
\hline \multicolumn{4}{|c|}{ BACTERIA } \\
\hline THP-1 & SEC & EM, FC, and TRPS & [40] \\
\hline THP-1 & Isolation kit & EM and WB & [41] \\
\hline MDM & Isolation kit & EM, NTA, and miRNA content & [42] \\
\hline THP-1 & Isolation kit & EM, NTA, and WB & [43] \\
\hline THP-1 & Isolation kit & EM, NTA, miRNA content, and WB & [44] \\
\hline THP-1 & Isolation kit & EM, NTA, PT, and WB & [45] \\
\hline THP-1 & UC and sucrose density gradient separation & EM, FC, and WB & [46] \\
\hline THP-1 & UC & $\mathrm{EM}, \mathrm{FC}$, and PT & [47] \\
\hline THP-1 & UC & PT & [48] \\
\hline THP-1 & $\mathrm{UC}$ & EM, FC, and PT & [49] \\
\hline THP-1 & Isolation kit & EM & [50] \\
\hline MDM & UC & EM, NTA, RNA-seq, and WB & [51] \\
\hline THP-1 & $\mathrm{UC}$ & EM, NTA, and WB & [52] \\
\hline THP-1 & $\begin{array}{l}\text { UC and iodixanol density gradient } \\
\text { separation }\end{array}$ & EM, NTA, PT, and WB & [53] \\
\hline \multicolumn{4}{|c|}{ VIRUSES } \\
\hline MDM & UC and sucrose density gradient separation & EM, LP, and PT & [54] \\
\hline U937 or MDM & $\begin{array}{l}\text { UC and iodixanol density gradient } \\
\text { separation }\end{array}$ & AChE activity and FC & [55] \\
\hline $\begin{array}{l}\text { THP-1 or primary human alveolar } \\
\text { macrophages }\end{array}$ & Isolation kit & miRNA content and RNA-seq & [56] \\
\hline MDM & $\begin{array}{l}\text { UC and iodixanol density gradient } \\
\text { separation }\end{array}$ & AChE activity, miRNA content, and WB & [57] \\
\hline THP-1 or MDM & $\mathrm{UC}$ & EM, NTA, and WB & [58] \\
\hline MDM & $\mathrm{UC}$ & EM, NTA, and WB & [59] \\
\hline MDM & Isolation kit & NTA and WB & [60] \\
\hline MDM or THP-1 & Isolation kit & NTA and miRNA content & [61] \\
\hline U937 & UC and sucrose density gradient separation & $\begin{array}{c}\text { AChE activity, EM, miRNA content, PT, } \\
\text { and WB }\end{array}$ & [62] \\
\hline THP-1 & UC & $\mathrm{EM}, \mathrm{FC}$, and WB & [63] \\
\hline THP-1 & Isolation kit & EM and WB & [64] \\
\hline MDM or THP- 1 & $\mathrm{UC}$ & NTA, EM, FC, and WB & [65] \\
\hline \multicolumn{4}{|c|}{ PARASITES } \\
\hline THP-1 & UC and sucrose density gradient separation & EM, FC, and WB & [46] \\
\hline THP-1 & UC & EM and FC & [66] \\
\hline THP-1 & SEC & EM, NTA, PT, and WB & [67] \\
\hline \multicolumn{4}{|c|}{ FUNGI } \\
\hline MDM & $\mathrm{UC}$ & EM, NTA, PT, and WB & [68] \\
\hline THP-1 & UC & DLS, EM, and PT & [69] \\
\hline
\end{tabular}

Abbreviations: UC, ultracentrifugation; SEC, size-exclusion chromatography; EM, electron microscopy; NTA, nanoparticle tracking analysis; WB, western blotting; PT, proteomic analysis; FC, flow cytometer; AChe, acetylcholinesterase activity; DLS, dynamic light scattering; LP, lipidomic analysis; TRPS, tunable resistive pulse sensing.

To date, methods based on differential centrifugation (dUC) or ultracentrifugation (UC) have been used by approximately $40 \%$ of the works, followed by isolation kits using polymer-based precipitation (33\%), sucrose or iodixanol gradient ultracentrifugation (20\%), and finally the size-exclusion chromatography (SEC; 7\%) (Figure 2). Each method presents advantages and shortcomings, and selecting the better method for a particular study depends on different factors, including the starting material of the cell culture, purity grade of cells, the volume of the cell conditioned medium, and the isolation purpose (e.g., research, therapeutic, or diagnostic use) [1].

We recently proposed a protocol based on sucrose density gradient ultracentrifugation (S-DGUC) with higher speeds $(130,000 \times g)$ that allowed the separation of large amounts of small EVs released by monocyte-derived human primary macrophages enriched with vesicles from endosomal origin [96]. This work showed the method reproducibility and feasibility by using macrophage samples from different healthy donors to recover approximately $80 \%$ of a heterogeneous population of primary macrophage-derived small EVs. We performed this work taking into account the limited number of studies describ- 
ing procedures for recovering small EVs from human primary macrophages, aiming to contribute with an improved method for research studying EVs from those cells [96]. To characterize $M \Phi-E V s$, most researchers apply their physical (e.g., size, morphology, particle concentration) and molecular/biochemical properties (e.g., surface marker expression, nucleic acid, lipid, and protein contents) (Table 2). They report the use of electron microscopy (transmission, scanning or cryogenic electron microscopy), western blotting, nanoparticle tracking analysis, proteomic analysis, flow cytometer, acetylcholinesterase activity, dynamic light scattering, lipidomic analysis, and tunable resistive pulse sensing, achieving a usage percentage of $25 \%, 18 \%, 14 \%, 10 \%, 8 \%, 6 \%, 3 \%$ and $1 \%$, respectively (Figure 2). The characterization techniques also present advantages and limitations [94]. Due to the minor differences in the physical properties and composition of the different EV subtypes, the combination of diverse techniques is required for qualitative and quantitative EVs characterization. In fact, the international society of extracellular vesicles (ISEV) recommends expanding the number of characterization methods to at least three or more independent techniques to describe heterogeneous populations of EVs [1]. The development and improvement of a large variety of advanced methods for EV analysis will be essential for the proper interpretation of results obtained in functional studies with EVs from different origins, potentially providing new opportunities for their applications in biomedical research and therapeutic purposes [97,98].

A)

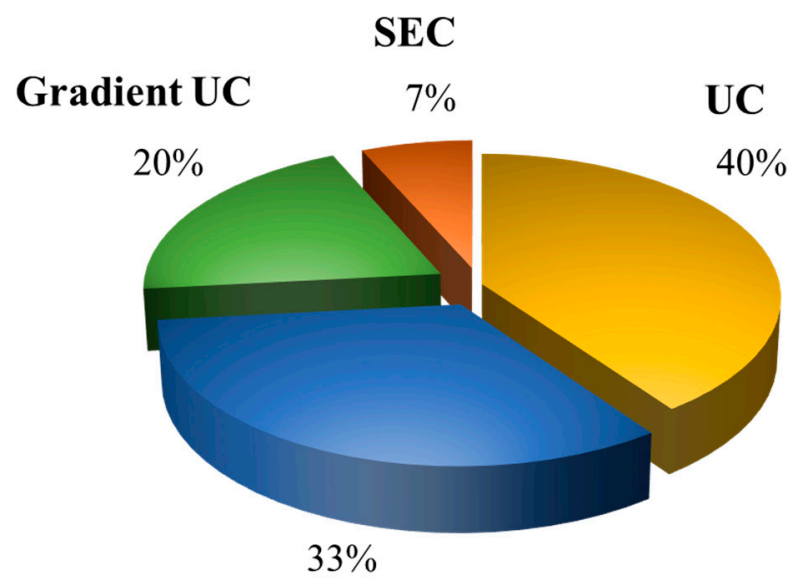

Isolation kits
B)

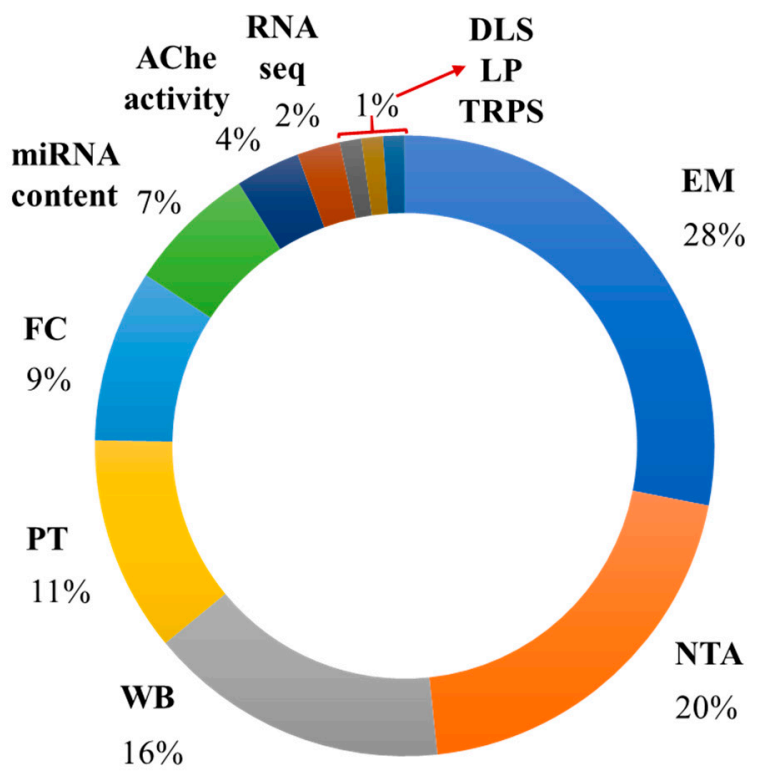

Figure 2. Pie chart of common technologies used for the separation and description of EVs released by human macrophages. (A) isolation and (B) characterization methods. Abbreviations: UC, ultracentrifugation; SEC, size-exclusion chromatography; EM, electron microscopy; NTA, nanoparticle tracking analysis; WB, western blotting; PT, proteomic analysis; FC, flow cytometer; AChe, acetylcholinesterase activity; DLS, dynamic light scattering; LP, lipidomic analysis; TRPS, tunable resistive pulse sensing.

\section{Macrophage-EVs as Diagnostic Markers for Infectious Diseases}

Increasing evidence suggests the potential role of human macrophages for diagnostic and prognostic biomarkers during infectious diseases [99-102]. For instance, Lidofsky and colleagues demonstrated that soluble hemoglobin scavenger receptor (sCD163) from macrophages in patients infected with HIV-1 and HCV was positively associated with the severity of liver fibrosis from mild to moderate stage, with an Ishak fibrosis score up to 4 , but not in established cirrhosis [103]. Moreover, the soluble form of the mannose receptor (sMR, sCD206) expressed by macrophages was significantly elevated in patients with sepsis and in those who died within 28 days. In addition, higher sensitivity of sMR was 
found to better predict mortality than other inflammatory markers such as procalcitonin (PCT), C-reactive protein (CRP), and sCD163 [104]. Serum expression levels of miR-145 from macrophages were observed to distinguishing Mtb-infected patients from healthy individuals and differentiating between active and latent tuberculosis cases [105]. Similarly, macrophages containing SARS-CoV-2 viral particles were found to express high levels of IL-6, and the presence of this inflammatory mediator was associated with severe depletion of lymphocytes from the spleen and lymph nodes in severe Coronavirus disease 2019 (COVID-19) patients [106].

In the last decade, EVs have attracted enormous research interest for their promising medical applications $[77,107,108]$. Vesicles may serve as disease diagnostic tools because they transport origin-specific subsets of nucleic acid (e.g., specifics miRNAs) and proteins that likely correlate to cell-type-associated functions $[109,110]$. These data and other studies quoted in this present review suggest that EVs secreted by infected human macrophages may carry miRNAs and/or protein signatures that closely reflect the associated clinical pathophysiology status in infectious diseases. Nonetheless, further studies using M $\Phi$-EVs are necessary to understand and prove their potential use as diagnostic markers. Future investments on macrophage EVs-based tools could be a good strategy for diagnosing and prognosis of several human infectious diseases. Numerous advantages have been proposed for using EV-based diagnostics from other cellular models, such as reduction in patient pain, stress-free and low-cost alternatives compared with conventional techniques (e.g., excision biopsies or traditional needle biopsies) [111].

\section{Concluding Remarks}

Extracellular vesicles from human macrophages have been on the central stage of many functional studies dealing with steady-state homeostasis or pathological conditions, especially in host-pathogen scenario. Although there is still much to be learned about their implication in the physio-pathogenesis of infectious disease, considerable knowledge has been gained in recent years. According to available evidence, EVs secreted by human macrophages may favor pathogen growth and dissemination in the following ways. (1) EVs from infected cells can trigger the secretion of pro-inflammatory cytokines in recipient cells via activation of specific cell signaling pathways (e.g., NF-kB). (2) M $\Phi$-EVs from infected cells can reprogram recipient cell metabolism pathways and modulated immune surveillance through specific miRNA transference. (3) EVs can be exploited by pathogens as alternative strategy to export microbial components (e.g., proteins, RNAs, miRNAs) to impair host defense and promote infectivity and propagation (Figure 3). On the contrary, these EVs can reduce the replication of infectious agents by (1) transporting PAMPs or pathogens antigens to enhance the expression of chemokines and recruitment of leukocytes and stimulate the secretion of pro-inflammatory mediators to diminish cell permissiveness to pathogen invasion. (2) Transferring or stimulating in recipient cell the secretion of proteins and molecules with anti-pathogenic effects, such as IFN- $\gamma$, IL-1 $\beta$, IL-8, IL-6, IL-10, IP-10, TNF- $\alpha$ (Figure 4). Overall, these studies indicate that EVs from human macrophages can either enhance or impair the host anti-pathogenic response. 


\section{PRO-PATHOGENIC EFFECTS}

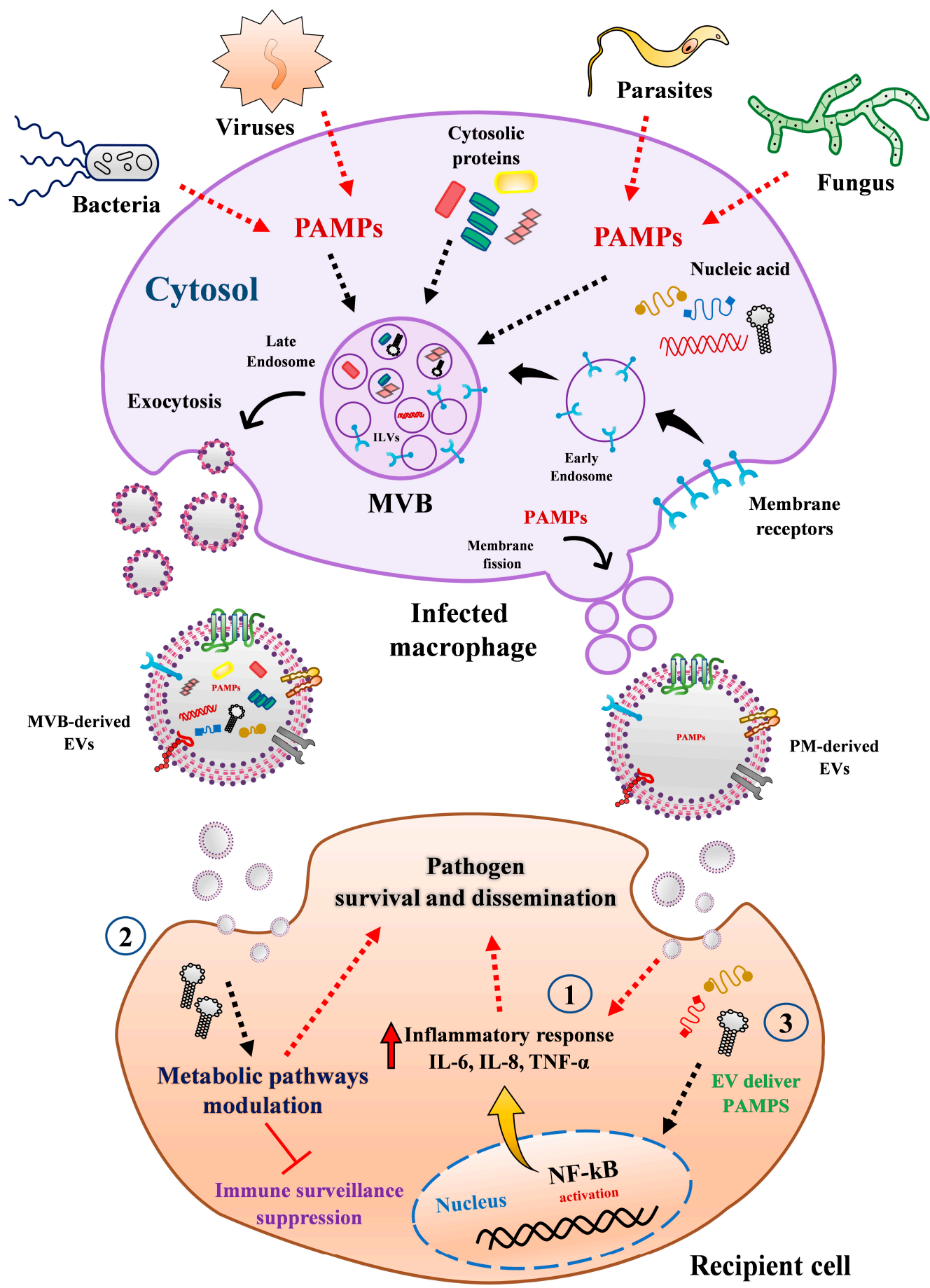

Figure 3. Pro-pathogenic effect mediated by EVs released from human macrophages. Macrophages infected with bacteria, virus, parasite, or fungi secreted heterogenous populations of EVs from different origin and sizes, which may favor pathogen growth and propagation through multiple mechanisms. For instance, (1) EVs from infected cells can trigger the secretion of pro-inflammatory cytokines (e.g., IL-6, IL-8, TNF- $\alpha$ ) in recipient cells via activation of NF-kB pathway. (2) M $\Phi-E V s$ from infected cells can reprogram recipient cell metabolism pathways and modulated immune surveillance through transferring specific miRNAs. (3) EVs can be exploited by pathogens as alternative strategy to export microbial components (e.g., proteins, RNAs, miRNAs) to impair host defense and promote their infectivity and propagation. Abbreviations: MVBs, multivesicular bodies; PAMPs, pathogen-associated molecular patterns; PM, plasma membrane. 


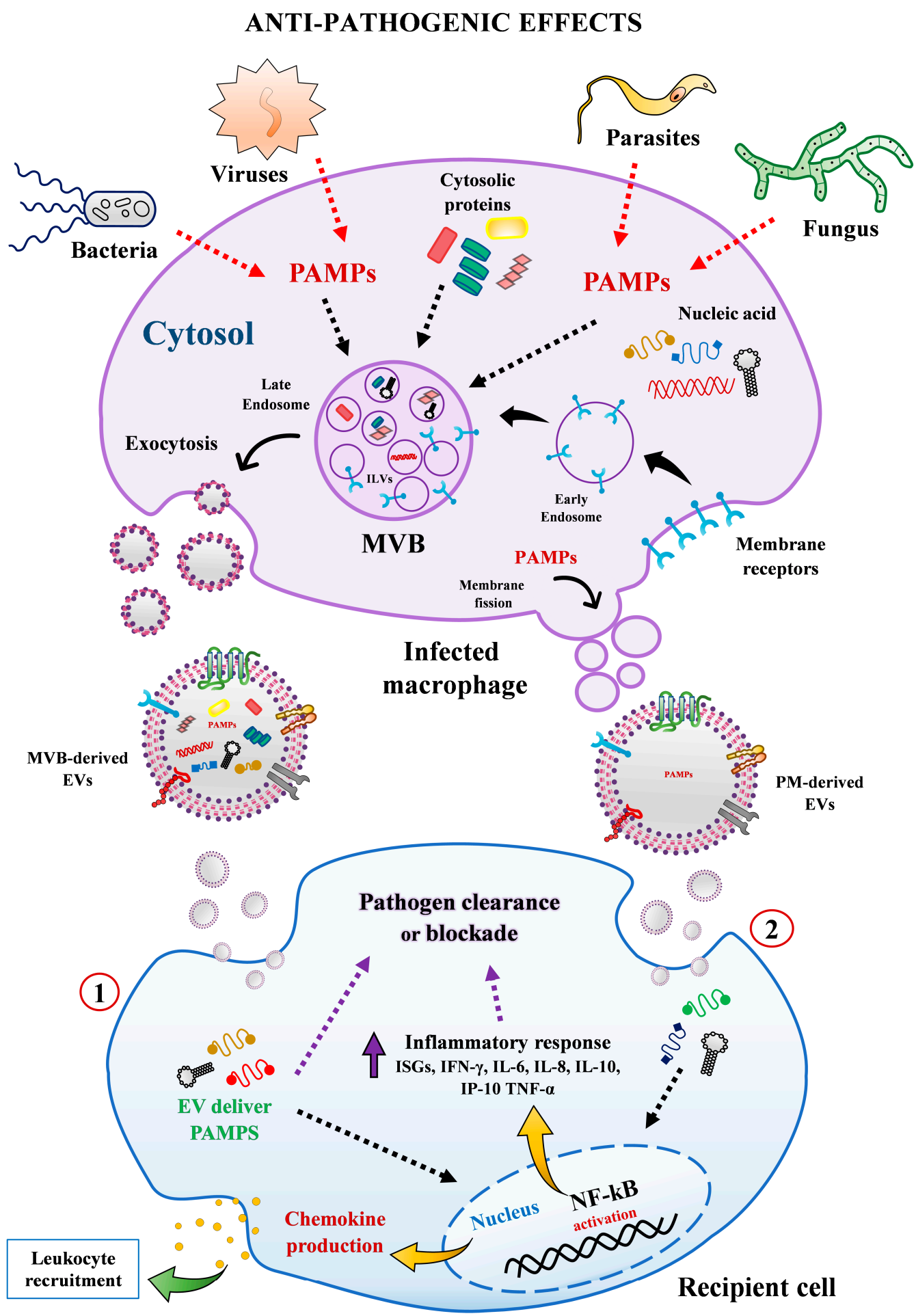

Figure 4. Anti-pathogenic effect mediated by EVs released from human macrophages. EVs secreted by infected macrophages may stimulate the clearance or blockade of pathogen growth in recipient cells by the following ways: (1) transporting PAMPs or pathogens antigens to enhance the expression of chemokines and recruitment of leukocytes to control the pathogen dissemination. (2) Transferring or stimulating proteins and molecules with anti-pathogenic effects, such as IFN- $\gamma$, IL-1 $\beta$, IL-8, IL-6, IL-10, IP-10, TNF- $\alpha$ to diminish cell permissiveness to pathogen invasion. Abbreviations: MVBs, multivesicular bodies; PAMPs, pathogen-associated molecular patterns; PM, plasma membrane.

The functional relevance of EVs from human macrophages during infection diseases is incompletely characterized. Future studies centering on their production, composition, 
diversity, and physiology may clarify various questions that remain open. Scientific efforts in the field may seek to develop advanced methodologies to allow full-scale recovery of particles, and to discriminate relevant subpopulations for the proper interpretation of EV-related studies. In summary, understanding the host-pathogens interactions in the context of human macrophage-EV-mediated cellular communication may provide new insights for future innovative therapeutic development based on the physiologic roles of extracellular vesicles.

Author Contributions: L.A.A.-B.: conceptualization, formal analysis, investigation, figure edition, data curation, writing — original draft preparation, writing—review and editing. D.C.B.-H.: conceptualization, writing - review and editing, supervision, project administration, funding acquisition. All authors have read and agreed to the published version of the manuscript.

Funding: This research was funded by Brazilian National Research Council (CNPq, grant \# 475958/20110), Carlos Chagas Filho Rio de Janeiro Research Foundation (FAPERJ, grant \# E-26/102.972/2011), Oswaldo Cruz Foundation (INOVA Program, grant \# 3440295262); Mercosur Fund for Structural Convergence (FOCEM, grant \# 03/11).

Institutional Review Board Statement: Not applicable.

Informed Consent Statement: Not applicable.

Data Availability Statement: The authors declare that all data presented in this manuscript are fully available.

Acknowledgments: The opening sentences of this paper were written by the author DCBH echoing the Nobel Prize of Literature Gabriel Garcia Márquez. The authors are grateful to Rodrigo P. Soares (René Rachou Institute/Fiocruz, MG, Brazil) for helpful discussions and stimulating comments, and to the Hemotherapy Service of the Hospital Clementino Fraga Filho (Federal University of Rio de Janeiro, Brazil) for providing buffy coats for their studies with peripheral blood mononuclear cells from healthy donors.

Conflicts of Interest: The authors declare no conflict of interest.

\section{References}

1. Théry, C.; Witwer, K.W.; Aikawa, E.; Alcaraz, M.J.; Anderson, J.D.; Andriantsitohaina, R.; Antoniou, A.; Arab, T.; Archer, F.; Atkin-Smith, G.K.; et al. Minimal information for studies of extracellular vesicles 2018 (MISEV2018): A position statement of the International Society for Extracellular Vesicles and update of the MISEV2014 guidelines. J. Extracell. Vesicles 2018, 7. [CrossRef]

2. Witwer, K.W.; Théry, C. Extracellular vesicles or exosomes? On primacy, precision, and popularity influencing a choice of nomenclature. J. Extracell. Vesicles 2019, 8. [CrossRef] [PubMed]

3. Colombo, M.; Raposo, G.; Théry, C. Biogenesis, secretion, and intercellular interactions of exosomes and other extracellular vesicles. Annu. Rev. Cell Dev. Biol. 2014, 30, 255-289. [CrossRef] [PubMed]

4. Van Niel, G.; D'Angelo, G.; Raposo, G. Shedding light on the cell biology of extracellular vesicles. Nat. Rev. Mol. Cell Biol. 2018, 19, 213-228. [CrossRef] [PubMed]

5. Yáñez-Mó, M.; Siljander, P.R.-M.; Andreu, Z.; Zavec, A.B.; Borràs, F.E.; Buzas, E.I.; Buzas, K.; Casal, E.; Cappello, F.; Carvalho, J.; et al. Biological Properties of Extracellular Vesicles and their Physiological Functions. J. Extracell. Vesicles 2015, 4, 27066. [CrossRef] [PubMed]

6. Mathieu, M.; Martin-Jaular, L.; Lavieu, G.; Théry, C. Specificities of secretion and uptake of exosomes and other extracellular vesicles for cell-to-cell communication. Nat. Cell Biol. 2019. [CrossRef] [PubMed]

7. Cocucci, E.; Racchetti, G.; Podini, P.; Meldolesi, J. Enlargeosome Traffic: Exocytosis Triggered by Various Signals Is Followed by Endocytosis, Membrane Shedding or Both. Traffic 2007, 8, 742-757. [CrossRef]

8. Tkach, M.; Kowal, J.; Théry, C. Why the need and how to approach the functional diversity of extracellular vesicles. Philos. Trans. R. Soc. B Biol. Sci. 2018, 373. [CrossRef]

9. Johnstone, R.M.; Adam, M.; Hammond, J.R.; Orr, L.; Turbide, C. Vesicle formation during reticulocyte maturation. Association of plasma membrane activities with released vesicles (exosomes). J. Biol. Chem. 1987, 262, 9412-9420. [CrossRef]

10. Skotland, T.; Hessvik, N.P.; Sandvig, K.; Llorente, A. Exosomal lipid composition and the role of ether lipids and phosphoinositides in exosome biology. J. Lipid Res. 2019, 60, 9-18. [CrossRef]

11. Marcilla, A.; Jaular, L.M.; Trelis, M.; Menezes-Neto, A.; Osuna, A.; Bernal, D.; Fernandez-Becerra, C.; Almeida, I.; Del Portillo, H.A. Extracellular vesicles in parasitic diseases. J. Extracell. Vesicles 2014. [CrossRef] [PubMed]

12. Schorey, J.S.; Harding, C.V. Extracellular vesicles and infectious diseases: New complexity to an old story. J. Clin. Investig. 2016, 1181-1189. [CrossRef] [PubMed] 
13. Caobi, A.; Nair, M.; Raymond, A.D. Extracellular Vesicles in the Pathogenesis of Viral Infections in Humans. Viruses 2020, 12, 1200. [CrossRef]

14. Coakley, G.; Maizels, R.M.; Buck, A.H. Exosomes and Other Extracellular Vesicles: The New Communicators in Parasite Infections. Trends Parasitol. 2015, 477-489. [CrossRef] [PubMed]

15. Kuipers, M.E.; Hokke, C.H.; Smits, H.H.; Hoen, E.N.M.N. T Pathogen-Derived Extracellular Vesicle-Associated Molecules That Affect the Host Immune System: An Overview. Front. Microbiol. 2018. [CrossRef]

16. Rizzo, J.; Rodrigues, M.L.; Janbon, G. Extracellular Vesicles in Fungi: Past, Present, and Future Perspectives. Front. Cell. Infect. Microbiol. 2020, 346. [CrossRef]

17. Spencer, N.; Yeruva, L. Role of bacterial infections in extracellular vesicles release and impact on immune response. Biomed. J. 2020. [CrossRef]

18. Torrecilhas, A.C.; Soares, R.P.; Schenkman, S.; Fernández-Prada, C.; Olivier, M. Extracellular Vesicles in Trypanosomatids: Host Cell Communication. Front. Cell. Infect. Microbiol. 2020, 750. [CrossRef]

19. Costa, A.O.; Chagas, I.A.R.; de Menezes-Neto, A.; Rêgo, F.D.; Nogueira, P.M.; Torrecilhas, A.C.; Furst, C.; Fux, B.; Soares, R.P. Distinct immunomodulatory properties of extracellular vesicles released by different strains of Acanthamoeba. Cell Biol. Int. 2021, 45, 1060-1071. [CrossRef]

20. Gordon, S. The macrophage: Past, present and future. Eur. J. Immunol. 2007, 37, S9-S17. [CrossRef]

21. Gordon, S.; Martinez-Pomares, L. Physiological roles of macrophages. Pflüg. Arch. Eur. J. Physiol. 2017, 469, 365-374. [CrossRef]

22. Wynn, T.A.; Chawla, A.; Pollard, J.W. Macrophage biology in development, homeostasis and disease. Nature 2013, 496, 445-455. [CrossRef]

23. Flannagan, R.; Heit, B.; Heinrichs, D.E. Antimicrobial Mechanisms of Macrophages and the Immune Evasion Strategies of Staphylococcus aureus. Pathogens 2015, 4, 826-868. [CrossRef] [PubMed]

24. Jurberg, A.D.; Cotta-De-Almeida, V.; Temerozo, J.; Savino, W.; Bou-Habib, D.C.; Riederer, I. Neuroendocrine Control of Macrophage Development and Function. Front. Immunol. 2018, 9, 1440. [CrossRef]

25. Gracia-Hernandez, M.; Sotomayor, E.M.; Villagra, A. Targeting Macrophages as a Therapeutic Option in Coronavirus Disease 2019. Front. Pharmacol. 2020, 11, 577571. [CrossRef]

26. Torraca, V.; Masud, S.; Spaink, H.; Meijer, A.H. Macrophage-pathogen interactions in infectious diseases: New therapeutic insights from the zebrafish host model. Dis. Model. Mech. 2014, 785-797. [CrossRef]

27. Atri, C.; Guerfali, F.Z.; Laouini, D. Role of Human Macrophage Polarization in Inflammation during Infectious Diseases. Int. J. Mol. Sci. 2018, 19, 1801. [CrossRef] [PubMed]

28. Xu, R.; Rai, A.; Chen, M.; Suwakulsiri, W.; Greening, D.W.; Simpson, R.J. Extracellular vesicles in cancer-Implications for future improvements in cancer care. Nat. Rev. Clin. Oncol. 2018, 617-638. [CrossRef] [PubMed]

29. Wu, W.-C.; Song, S.-J.; Zhang, Y.; Li, X. Role of Extracellular Vesicles in Autoimmune Pathogenesis. Front. Immunol. 2020, 579043. [CrossRef]

30. Yin, Z.; Fan, J.; Xu, J.; Wu, F.; Li, Y.; Zhou, M.; Liao, T.; Duan, L.; Wang, S.; Geng, W.; et al. Immunoregulatory Roles of Extracellular Vesicles and Associated Therapeutic Applications in Lung Cancer. Front. Immunol. 2020. [CrossRef]

31. Kowal, J.; Tkach, M. Dendritic cell extracellular vesicles. Int. Rev. Cell Mol. Biol. 2019, 213-249. [CrossRef]

32. Federici, C.; Shahaj, E.; Cecchetti, S.; Camerini, S.; Casella, M.; Iessi, E.; Camisaschi, C.; Paolino, G.; Calvieri, S.; Ferro, S.; et al. Natural-killer-derived extracellular vesicles: Immune sensors and interactors. Front. Immunol. 2020, 11. [CrossRef] [PubMed]

33. Kormelink, T.G.; Mol, S.; De Jong, E.C.; Wauben, M. The role of extracellular vesicles when innate meets adaptive. Semin. Immunopathol. 2018, 439-452. [CrossRef]

34. Ismail, N.; Wang, Y.; Dakhlallah, D.; Moldovan, L.; Agarwal, K.; Batte, K.; Shah, P.; Wisler, J.; Eubank, T.D.; Tridandapani, S.; et al. Macrophage microvesicles induce macrophage differentiation and miR-223 transfer. Blood 2013, 121, 984-995. [CrossRef] [PubMed]

35. Cheng, L.; Wang, Y.; Huang, L. Exosomes from M1-Polarized Macrophages Potentiate the Cancer Vaccine by Creating a Pro-inflammatory Microenvironment in the Lymph Node. Mol. Ther. 2017, 25, 1665-1675. [CrossRef]

36. Wang, Y.; Zhao, M.; Liu, S.; Guo, J.; Lu, Y.; Cheng, J.; Liu, J. Macrophage-derived extracellular vesicles: Diverse mediators of pathology and therapeutics in multiple diseases. Cell Death Dis. 2020. [CrossRef] [PubMed]

37. Giri, P.K.; Schorey, J.S. Exosomes Derived from M. Bovis BCG Infected Macrophages Activate Antigen-Specific CD4+ and CD8+ T Cells in vitro and in vivo. PLoS ONE 2008, 3, e2461. [CrossRef]

38. Robbins, P.D.; Morelli, A.E. Regulation of immune responses by extracellular vesicles. Nat. Rev. Immunol. 2014, 195-208. [CrossRef]

39. Rodrigues, M.; Fan, J.; Lyon, C.; Wan, M.; Hu, T. Role of Extracellular Vesicles in Viral and Bacterial Infections: Pathogenesis, Diagnostics, and Therapeutics. Theranostics 2018, 2709-2721. [CrossRef]

40. Volgers, C.; Benedikter, B.J.; Grauls, G.E.; Savelkoul, P.H.M.; Stassen, F.R.M. Immunomodulatory role for membrane vesicles released by THP-1 macrophages and respiratory pathogens during macrophage infection. BMC Microbiol. 2017, 17, 216. [CrossRef]

41. Carrière, J.; Bretin, A.; Darfeuille-Michaud, A.; Barnich, N.; Nguyen, H.T.T. Exosomes Released from Cells Infected with Crohn's Disease-Associated Adherent-Invasive Escherichia coli Activate Host Innate Immune Responses and Enhance Bacterial Intracellular Replication. Inflamm. Bowel Dis. 2016, 22, 516-528. [CrossRef] [PubMed] 
42. Alipoor, S.D.; Mortaz, E.; Tabarsi, P.; Farnia, P.; Mirsaeidi, M.; Garssen, J.; Movassaghi, M.; Adcock, I.M. Bovis Bacillus CalmetteGuerin (BCG) infection induces exosomal miRNA release by human macrophages. J. Transl. Med. 2017, 15. [CrossRef]

43. Xu, B.-F.; Wang, Q.-Q.; Zhang, J.-P.; Hu, W.-L.; Zhang, R.-L. Treponema pallidum induces the activation of endothelial cells via macrophage-derived exosomes. Arch. Dermatol. Res. 2019, 311, 121-130. [CrossRef] [PubMed]

44. Hu, W.; Xu, B.; Zhang, J.; Kou, C.; Liu, J.; Wang, Q.; Zhang, R. Exosomal miR-146a-5p from Treponema pallidum-stimulated macrophages reduces endothelial cells permeability and monocyte transendothelial migration by targeting JAM-C. Exp. Cell Res. 2020, 388. [CrossRef]

45. Diaz, G.; Wolfe, L.M.; Kruh-Garcia, N.; Dobos, K.M. Changes in the Membrane-Associated Proteins of Exosomes Released from Human Macrophages after Mycobacterium tuberculosis Infection. Sci. Rep. 2016, 6. [CrossRef]

46. Bhatnagar, S.; Shinagawa, K.; Castellino, F.J.; Schorey, J.S. Exosomes released from macrophages infected with intracellular pathogens stimulate a proinflammatory response in vitro and in vivo. Blood 2007, 110, 3234-3244. [CrossRef]

47. Walters, S.B.; Kieckbusch, J.; Nagalingam, G.; Swain, A.; Latham, S.L.; Grau, G.E.R.; Britton, W.J.; Combes, V.; Saunders, B.M. Microparticles from Mycobacteria-Infected Macrophages Promote Inflammation and Cellular Migration. J. Immunol. 2012, 190, 669-677. [CrossRef] [PubMed]

48. Hare, N.J.; Chan, B.; Chan, E.; Kaufman, K.L.; Britton, W.J.; Saunders, B. Microparticles released fromMycobacterium tuberculosisinfected human macrophages contain increased levels of the type I interferon inducible proteins including ISG15. Proteomics 2015, 15, 3020-3029. [CrossRef] [PubMed]

49. Wang, J.-J.; Chen, C.; Xie, P.-F.; Pan, Y.; Tan, Y.-H.; Tang, L.-J. Proteomic analysis and immune properties of exosomes released by macrophages infected with Mycobacterium avium. Microbes Infect. 2014, 16, 283-291. [CrossRef]

50. Wang, J.; Yao, Y.; Xiong, J.; Wu, J.; Tang, X.; Li, G. Evaluation of the Inflammatory Response in Macrophages Stimulated with Exosomes Secreted by Mycobacterium avium-Infected Macrophages. BioMed Res. Int. 2015, 2015, 658421. [CrossRef]

51. Pawar, K.; Shigematsu, M.; Sharbati, S.; Kirino, Y. Infection-induced 5'-half molecules of tRNAHisGUG activate Toll-like receptor 7. PLoS Biol. 2020, 18, e3000982. [CrossRef]

52. Jung, A.L.; Herkt, C.E.; Schulz, C.; Bolte, K.; Seidel, K.; Scheller, N.; Sittka-Stark, A.; Bertrams, W.; Schmeck, B. Legionella pneumophila infection activates bystander cells differentially by bacterial and host cell vesicles. Sci. Rep. 2017, 7. [CrossRef]

53. Hui, W.W.; Hercik, K.; Belsare, S.; Alugubelly, N.; Clapp, B.; Rinaldi, C.; Edelmann, M.J. Salmonella enterica Serovar Typhimurium Alters the Extracellular Proteome of Macrophages and Leads to the Production of Proinflammatory Exosomes. Infect. Immun. 2018, 86. [CrossRef]

54. Kadiu, I.; Narayanasamy, P.; Dash, P.K.; Zhang, W.; Gendelman, H.E. Biochemical and Biologic Characterization of Exosomes and Microvesicles as Facilitators of HIV-1 Infection in Macrophages. J. Immunol. 2012, 189, 744-754. [CrossRef] [PubMed]

55. Arenaccio, C.; Anticoli, S.; Manfredi, F.; Chiozzini, C.; Olivetta, E.; Federico, M. Latent HIV-1 is activated by exosomes from cells infected with either replication-competent or defective HIV-1. Retrovirology 2015, 12, 87. [CrossRef] [PubMed]

56. Bernard, M.A.; Zhao, H.; Yue, S.C.; Anandaiah, A.; Koziel, H.; Tachado, S.D. Novel HIV-1 MiRNAs Stimulate TNF $\alpha$ Release in Human Macrophages via TLR8 Signaling Pathway. PLoS ONE 2014, 9, e106006. [CrossRef]

57. Roth, W.W.; Huang, M.B.; Konadu, K.A.; Powell, M.D.; Bond, V.C. Micro RNA in Exosomes from HIV-Infected Macrophages. Int. J. Environ. Res. Public Health 2016, 13, 32. [CrossRef] [PubMed]

58. Yuan, Z.; Petree, J.R.; Lee, F.E.-H.; Fan, X.; Salaita, K.; Guidot, D.M.; Sadikot, R.T. Macrophages exposed to HIV viral protein disrupt lung epithelial cell integrity and mitochondrial bioenergetics via exosomal microRNA shuttling. Cell Death Dis. 2019, 10. [CrossRef] [PubMed]

59. Sharma, H.; Chinnappan, M.; Agarwal, S.; Dalvi, P.; Gunewardena, S.; O’Brien-Ladner, A.; Dhillon, N.K. Macrophage-derived extracellular vesicles mediate smooth muscle hyperplasia: Role of altered miRNA cargo in response to HIV infection and substance abuse. FASEB J. 2018, 32, 5174-5185. [CrossRef]

60. Cantres-Rosario, Y.M.; Ortiz-Rodríguez, S.C.; Santos-Figueroa, A.G.; Plaud, M.; Negron, K.; Cotto, B.; Langford, D.; Melendez, L.M. HIV Infection Induces Extracellular Cathepsin B Uptake and Damage to Neurons. Sci. Rep. 2019, 9. [CrossRef]

61. Okamoto, M.; Fukushima, Y.; Kouwaki, T.; Daito, T.; Kohara, M.; Kida, H.; Oshiumi, H. MicroRNA-451a in extracellular, blood-resident vesicles attenuates macrophage and dendritic cell responses to influenza whole-virus vaccine. J. Biol. Chem. 2018, 293, 18585-18600. [CrossRef] [PubMed]

62. Velandia-Romero, M.L.; Calderón-Peláez, M.A.; Balbás-Tepedino, A.; Márquez-Ortiz, R.A.; Madroñero, L.J.; Prieto, A.B.; Castellanos, J.E. Extracellular vesicles of U937 macrophage cell line infected with DENV-2 induce activation in endothelial cells EA.hy926. PLoS ONE 2020, 15, e0227030. [CrossRef] [PubMed]

63. Yao, Z.; Qiao, Y.; Li, X.; Chen, J.; Ding, J.; Bai, L.; Shen, F.; Shi, B.; Liu, J.; Peng, L.; et al. Exosomes Exploit the Virus Entry Machinery and Pathway to Transmit Alpha Interferon-Induced Antiviral Activity. J. Virol. 2018, 92. [CrossRef] [PubMed]

64. Zhou, Y.; Wang, X.; Sun, L.; Zhou, L.; Ma, T.; Song, L.; Wu, J.; Li, J.; Ho, W. Toll-like receptor 3-activated macrophages confer anti-HCV activity to hepatocytes through exosomes. FASEB J. 2016, 30, 4132-4140. [CrossRef]

65. Cai, C.; Koch, B.; Morikawa, K.; Suda, G.; Sakamoto, N.; Rueschenbaum, S.; Akhras, S.; Dietz, J.; Hildt, E.; Zeuzem, S.; et al. Macrophage-Derived Extracellular Vesicles Induce Long-Lasting Immunity Against Hepatitis C Virus which is Blunted by Polyunsaturated Fatty Acids. Front. Immunol. 2018, 9, 723. [CrossRef]

66. Cestari, I.; Ansa-Addo, E.; Deolindo, P.; Inal, J.; Ramirez, M.I. Trypanosoma cruziImmune Evasion Mediated by Host Cell-Derived Microvesicles. J. Immunol. 2012, 188, 1942-1952. [CrossRef] 
67. Cronemberger-Andrade, A.; Xander, P.; Soares, R.P.; Pessoa, N.L.; Campos, M.A.; Ellis, C.C.; Grajeda, B.; Ofir-Birin, Y.; Almeida, I.C.; Regev-Rudzki, N.; et al. Trypanosoma cruzi-Infected Human Macrophages Shed Proinflammatory Extracellular Vesicles That Enhance Host-Cell Invasion via Toll-Like Receptor 2. Front. Cell. Infect. Microbiol. 2020, 10, 99. [CrossRef]

68. Cypryk, W.; Öhman, T.; Eskelinen, E.-L.; Matikainen, S.; Nyman, T.A. Quantitative Proteomics of Extracellular Vesicles Released from Human Monocyte-Derived Macrophages upon $\beta$-Glucan Stimulation. J. Proteome Res. 2014, 13, 2468-2477. [CrossRef]

69. Reales-Calderón, J.A.; Vaz, C.; Monteoliva, L.; Molero, G.; Gil, C. Candida albicans Modifies the Protein Composition and Size Distribution of THP-1 Macrophage-Derived Extracellular Vesicles. J. Proteome Res. 2017, 16, 87-105. [CrossRef]

70. Anand, P.K.; Anand, E.; Bleck, C.; Anes, E.; Griffiths, G. Exosomal Hsp70 Induces a Pro-Inflammatory Response to Foreign Particles Including Mycobacteria. PLoS ONE 2010, 5, e10136. [CrossRef]

71. Floyd, K.; Raviglione, M.C.; Glaziou, P. Global Epidemiology of Tuberculosis. Semin. Respir. Crit. Care Med. 2018, 39, 271-285. [CrossRef] [PubMed]

72. Silva, D.R.; Mello, F.C.D.Q.; Migliori, G.B. Tuberculosis series 2020. J. Bras. Pneumol. 2020, 46. [CrossRef]

73. O'Neill, S.K.; Cao, Y.; Hamel, K.M.; Doodes, P.D.; Hutas, G.; Finnegan, A. Expression of CD80/86 on B cells is essential for autoreactive $\mathrm{T}$ cell activation and the development of arthritis. J. Immunol. 2007, 179, 5109-5116. [CrossRef] [PubMed]

74. Dias, M.V.S.; Costa, C.S.; DaSilva, L.L.P. The Ambiguous Roles of Extracellular Vesicles in HIV Replication and Pathogenesis. Front. Microbiol. 2018. [CrossRef]

75. Pérez, P.S.; Romaniuk, M.A.; Duette, G.A.; Zhao, Z.; Huang, Y.; Martin-Jaular, L.; Witwer, K.W.; Théry, C.; Ostrowski, M Extracellular vesicles and chronic inflammation during HIV infection. J. Extracell. Vesicles 2019, 8, 1687275. [CrossRef] [PubMed]

76. Urbanelli, L.; Buratta, S.; Tancini, B.; Sagini, K.; Delo, F.; Porcellati, S.; Emiliani, C. The Role of Extracellular Vesicles in Viral Infection and Transmission. Vaccines 2019, 7, 102. [CrossRef] [PubMed]

77. Ipinmoroti, A.O.; Matthews, Q.L. Extracellular Vesicles: Roles in Human Viral Infections, Immune-Diagnostic, and Therapeutic Applications. Pathogens 2020, 9, 1056. [CrossRef]

78. Giannessi, F.; Aiello, A.; Franchi, F.; Percario, Z.A.; Affabris, E. The Role of Extracellular Vesicles as Allies of HIV, HCV and SARS Viruses. Viruses 2020, 12, 571. [CrossRef]

79. Martins, S.D.T.; Alves, L.R. Extracellular Vesicles in Viral Infections: Two Sides of the Same Coin? Front. Cell. Infect. Microbiol. 2020, 10, 593170. [CrossRef]

80. Jiang, Y.; Cai, X.; Yao, J.; Guo, H.; Yin, L.; Leung, W.; Xu, C. Role of Extracellular Vesicles in Influenza Virus Infection. Front. Cell. Infect. Microbiol. 2020, 366. [CrossRef]

81. Votteler, J.; Sundquist, W.I. Virus Budding and the ESCRT Pathway. Cell Host Microbe 2013, 232-241. [CrossRef] [PubMed]

82. Sadeghipour, S.; Mathias, R.A. Herpesviruses hijack host exosomes for viral pathogenesis. Semin. Cell Dev. Biol. 2017, 91-100. [CrossRef] [PubMed]

83. Van Der Grein, S.G.; Defourny, K.A.Y.; Slot, E.F.J; Hoen, E.N.M.N. T Intricate relationships between naked viruses and extracellular vesicles in the crosstalk between pathogen and host. Semin. Immunopathol. 2018, 491-504. [CrossRef] [PubMed]

84. Konadu, K.A.; Chu, J.; Huang, M.B.; Amancha, P.K.; Armstrong, W.S.; Powell, M.D.; Villinger, F.; Bond, V.C. Association of Cytokines with Exosomes in the Plasma of HIV-1-Seropositive Individuals. J. Infect. Dis. 2015, 211, 1712-1716. [CrossRef]

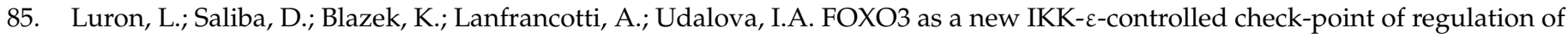
IFN- $\beta$ expression. Eur. J. Immunol. 2012, 42, 1030-1037. [CrossRef] [PubMed]

86. Rosenberger, C.M.; Podyminogin, R.L.; Navarro, G.; Zhao, G.-W.; Askovich, P.S.; Weiss, M.; Aderem, A. miR-451 Regulates Dendritic Cell Cytokine Responses to Influenza Infection. J. Immunol. 2012, 189, 5965-5975. [CrossRef]

87. Hassani, K.; Olivier, M. Immunomodulatory Impact of Leishmania-Induced Macrophage Exosomes: A Comparative Proteomic and Functional Analysis. PLoS Negl. Trop. Dis. 2013, 7, e2158. [CrossRef]

88. Ghosh, J.; Bose, M.; Roy, S.; Bhattacharyya, S.N. Leishmania donovani Targets Dicer1 to Downregulate miR-122, Lower Serum Cholesterol, and Facilitate Murine Liver Infection. Cell Host Microbe 2013, 13, 277-288. [CrossRef]

89. Cronemberger-Andrade, A.; Aragão-França, L.; De Araujo, C.F.; Rocha, V.J.; Silva, M.D.C.B.; Figueiras, C.P.; Oliveira, P.R.; De Freitas, L.A.R.; Veras, P.S.T.; Pontes-De-Carvalho, L. Extracellular Vesicles from Leishmania-Infected Macrophages Confer an Anti-infection Cytokine-Production Profile to Naïve Macrophages. PLoS Negl. Trop. Dis. 2014, 8, e3161. [CrossRef]

90. Gioseffi, A.; Hamerly, T.; Van, K.; Zhang, N.; Dinglasan, R.R.; Yates, P.A.; Kima, P.E. Leishmania-infected macrophages release extracellular vesicles that can promote lesion development. Life Sci. Alliance 2020, 3. [CrossRef]

91. Nieuwland, R.; Falcón-Pérez, J.M.; Théry, C.; Witwer, K.W. Rigor and standardization of extracellular vesicle research: Paving the road towards robustness. J. Extracell. Vesicles 2020, 10. [CrossRef]

92. Royo, F.; Théry, C.; Falcón-Pérez, J.M.; Nieuwland, R.; Witwer, K.W. Methods for Separation and Characterization of Extracellular Vesicles: Results of a Worldwide Survey Performed by the ISEV Rigor and Standardization Subcommittee. Cells 2020, 9, 1955. [CrossRef]

93. Chiriacò, M.S.; Bianco, M.; Nigro, A.; Primiceri, E.; Ferrara, F.; Romano, A.; Quattrini, A.; Furlan, R.; Arima, V.; Maruccio, G. Lab-on-Chip for Exosomes and Microvesicles Detection and Characterization. Sensors 2018, 18, 3175. [CrossRef]

94. Hartjes, T.A.; Mytnyk, S.; Jenster, G.W.; Van Steijn, V.; Van Royen, M.E. Extracellular Vesicle Quantification and Characterization: Common Methods and Emerging Approaches. Bioengineering 2019, 6, 7. [CrossRef]

95. Sidhom, K.; Obi, P.O.; Saleem, A. A Review of Exosomal Isolation Methods: Is Size Exclusion Chromatography the Best Option? Int. J. Mol. Sci. 2020, 21, 6466. [CrossRef] [PubMed] 
96. Arteaga-Blanco, L.A.; Mojoli, A.; Monteiro, R.Q.; Sandim, V.; Menna-Barreto, R.F.S.; Pereira-Dutra, F.S.; Bozza, P.T.; Resende, R.D.O.; Bou-Habib, D.C. Characterization and internalization of small extracellular vesicles released by human primary macrophages derived from circulating monocytes. PLoS ONE 2020, 15, e0237795. [CrossRef] [PubMed]

97. Stremersch, S.; De Smedt, S.C.; Raemdonck, K. Therapeutic and diagnostic applications of extracellular vesicles. J. Control. Release 2016, 244, 167-183. [CrossRef] [PubMed]

98. Sahoo, S.; Adamiak, M.; Mathiyalagan, P.; Kenneweg, F.; Kafert-Kasting, S.; Thum, T. Therapeutic and Diagnostic Translation of Extracellular Vesicles in Cardiovascular Diseases. Circulation 2021, 143, 1426-1449. [CrossRef]

99. Ka, M.B.; Daumas, A.; Textoris, J.; Mege, J.-L. Phenotypic Diversity and Emerging New Tools to Study Macrophage Activation in Bacterial Infectious Diseases. Front. Immunol. 2014. [CrossRef]

100. Merad, M.; Martin, J.C. Author Correction: Pathological inflammation in patients with COVID-19: A key role for monocytes and macrophages. Nat. Rev. Immunol. 2020, 20, 355-362. [CrossRef] [PubMed]

101. Moin, A.S.M.; Sathyapalan, T.; Diboun, I.; Atkin, S.L.; Butler, A.E. Identification of macrophage activation-related biomarkers in obese type 2 diabetes that may be indicative of enhanced respiratory risk in COVID-19. Sci. Rep. 2021, 11. [CrossRef] [PubMed]

102. Zhang, C.; Yang, M.; Ericsson, A.C. Function of Macrophages in Disease: Current Understanding on Molecular Mechanisms. Front. Immunol. 2021, 620510. [CrossRef]

103. Lidofsky, A.; Holmes, J.A.; Feeney, E.R.; Kruger, A.J.; Salloum, S.; Zheng, H.; Seguin, I.S.; Altinbas, A.; Masia, R.; Corey, K.E.; et al. Macrophage Activation Marker Soluble CD163 Is a Dynamic Marker of Liver Fibrogenesis in Human Immunodeficiency Virus/Hepatitis C Virus Coinfection. J. Infect. Dis. 2018, 218, 1394-1403. [CrossRef] [PubMed]

104. Relster, M.M.; Gaini, S.; Møller, H.J.; Johansen, I.S.; Pedersen, C. The macrophage activation marker sMR as a diagnostic and prognostic marker in patients with acute infectious disease with or without sepsis. Scand. J. Clin. Lab. Investig. 2018, 78, 180-186. [CrossRef]

105. Fu, Y.; Yang, X.; Chen, H.; Lu, Y. Diagnostic value of miR-145 and its regulatory role in macrophage immune response in tuberculosis. Genet. Mol. Biol. 2020, 43. [CrossRef]

106. Hadjadj, J.; Yatim, N.; Barnabei, L.; Corneau, A.; Boussier, J.; Smith, N.; Péré, H.; Charbit, B.; Bondet, V.; Chenevier-Gobeaux, C.; et al. Impaired type I interferon activity and inflammatory responses in severe COVID-19 patients. Science 2020, 369, 718-724. [CrossRef] [PubMed]

107. György, B.; Hung, M.; Breakefield, X.O.; Leonard, J.N. Therapeutic Applications of Extracellular Vesicles: Clinical Promise and Open Questions. Annu. Rev. Pharmacol. Toxicol. 2015, 55, 439-464. [CrossRef] [PubMed]

108. Crenshaw, B.J.; Sims, B.; Matthews, Q.L. Biological Function of Exosomes as Diagnostic Markers and Therapeutic Delivery Vehicles in Carcinogenesis and Infectious Diseases. Nanomedicines 2019. [CrossRef]

109. Rontogianni, S.; Synadaki, E.; Li, B.; Liefaard, M.C.; Lips, E.H.; Wesseling, J.; Wu, W.; Altelaar, M. Proteomic profiling of extracellular vesicles allows for human breast cancer subtyping. Commun. Biol. 2019, 2. [CrossRef]

110. Weber, B.; Franz, N.; Marzi, I.; Henrich, D.; Leppik, L. Extracellular vesicles as mediators and markers of acute organ injury: Current concepts. Eur. J. Trauma Emerg. Surg. 2021. [CrossRef]

111. Vlassov, A.V.; Magdaleno, S.; Setterquist, R.; Conrad, R. Exosomes: Current knowledge of their composition, biological functions, and diagnostic and therapeutic potentials. Biochim. Biophys. Acta Gen. Subj. 2012, 940-948. [CrossRef] [PubMed] 